\title{
MOŻLIWOŚCI I OGRANICZENIA ILOŚCIOWEJ ANALIZY ZAWARTOŚCI BAZ DANYCH WIZUALNYCH. SCHEMAT ANALIZY FOTOGRAFII ZEBRANYCH W RAMACH PROJEKTU „NIEWIDZIALNE MIASTO”
}

\begin{abstract}
Podgórski Michał, Możliwości i ograniczenia ilościowej analizy zawartości baz danych wizualnych. Schemat analizy fotografii zebranych w ramach projektu "Niewidzialne miasto" [Possibilities and limitations of quantitative analysis of bases of visual data. Scheme of analysis of photos gathered under the "Invisible city" project] edited by M. Krajewski - "Człowiek i Społeczeństwo", vol. XXXVI, iss. 2, Poznań 2013, pp. 327-348. Adam Mickiewicz University Press. ISBN 978-83-232-2672-7. ISSN 0239-3271.

The article presents possibilities and limitations of quantitative analysis of databases of visual data (in this case it is analysis of database of photos). The axis of the article is analysis of database of "Invisible city" project (web page: http:/ /www.niewidzialnemiasto.pl/), its first goal was photographic documentation of grassroots forms of modification of city space done by inhabitants of large Polish cities (broadly speaking this informal activity reduces to beautification of life environment and to improvement of its functionality). The moment the database of "Invisible city" project had grown to the size of several thousands of pictures, the idea arose that collected material can be analyzed in a quantitative way, which would enable more general, systematic view on phenomenon interesting for researchers.

In the article, firstly, there are presented tools, scheme and general results of analysis of photos gathered in database of "Invisible city" project, here, in other words, is presented the scheme of transformation of visual data to numerical data. Secondly, there are identified moments where the scheme of quantitative analysis of "Invisible city" fails, where it may result in information loss, doesn't give us one hundred percent certainty for obtained results (problems of first kind are connected with dynamics of the formation and growth of database, problems of second kind arise at the stage of pictures analysis). Thirdly, there is proposed and described one potential master (meta)analysis, that we can impose on analysis of database of visual data of "Invisible city" project in order to check its accuracy. Despite of mentioned above problems, difficulties associated with the fact that database of "Invisible city" was created spontaneously to some extent (it was balancing between database and photo gallery sometimes), results of quantitative analyzes are reliable, they reconstruct the dynamics of invisible city with accuracy and give strong foundation for in-depth description.
\end{abstract}

Michał Podgórski, Uniwersytet im. Adama Mickiewicza w Poznaniu, Instytut Socjologii, ul. Szamarzewskiego 89c, 60-569 Poznań, Poland.

\section{PROJEKT "NIEWIDZIALNE MIASTO"}

W ostatecznym kształcie projekt „Niewidzialne miasto"1 przyjął dwa cele: po pierwsze, chodziło (chodzi) o fotograficzną (i filmową - w później-

1 Zgodnie z konwencją przyjętą przez osoby tworzące projekt „Niewidzialne miasto” i piszące o nim, stosując zapis "Niewidzialne miasto" (NM), będę miał na myśli projekt reali- 
szej fazie) dokumentację i prezentację oddolnych trybów modyfikowania przestrzeni miejskiej przez mieszkańców dużych polskich miast oraz, po drugie, o ich socjologiczne opracowanie, zrozumienie. Piszę „w ostatecznym kształcie", ponieważ początki projektu było dość rozmyte. O ile cel pierwszy był (jest) treścią NM od zarania (był to w istocie cel założycielski), o tyle cel drugi, jakkolwiek zakładany (lub tylko myślany) od początku, dojrzewał z czasem. To dojrzewanie będzie miało pewien wpływ na etap ilościowej analizy zawartości bazy danych wizualnych zebranych w ramach projektu "Niewidzialne miasto” (bazy zgromadzonych fotografii), który to etap jest przedmiotem niniejszego tekstu.

Projekt "Niewidzialne miasto" funkcjonuje w wirtualnej przestrzeni publicznej i piśmiennictwie naukowym już od kilku dobrych lat, nie ma więc potrzeby omawiać go tutaj szczegółowo po raz kolejny, podam zatem tylko kilka niezbędnych informacji dotyczących NM, które pozwolą czytelnikowi swobodnie poruszać się w przestrzeni niniejszego tekstu. Mówiąc najogólniej, „niewidzialne miasto” stanowi sumę pozainstytucjonalnych, oddolnych, spontanicznych działań podejmowanych przez mieszkańców dużych polskich ${ }^{2}$ miast $\mathrm{w}$ celu dostosowywania przestrzeni miejskiej do własnych potrzeb, a więc czynienia jej bardziej funkcjonalną, elastyczną, dostępną (niedostępną), przyjazną (wrogą), estetyczną, sakralną, odświętną etc. Ogół nm twórcy projektu zredukowali do 16 kategorii, wskazując na: formy architektoniczne, czy też paraarchitektoniczne (Architektura), środki estetyzacji środowiska życia (Upiększenia, Bramy i ogrodzenia, Ogrody), rozwiązania podnoszące poziom bezpieczeństwa, odstraszające potencjalnych intruzów (Bezpieczeństwo), udoskonalone, przetworzone (przeinaczone) lub poddane estetyzacji samochody (Mobile), manifestacje i obiektywizacje wiary (Sakralne), uczestnictwo w świętach religijnych i państwowych (Odświętne), poglądy polityczne (Polityczne), formy zwiększania funkcjonalności, reperowania (miejskiego) środowiska życia (Użyteczne, Protezy instytucji), nieformalne, na poły legalne miejsca spotkań (Agory i kluby), wytwarzane przez dzieci miejsca zabaw (Miejsca dziecięce), ekonomię i reklamę hand made (Reklama), momenty styku - harmonii, koegzystencji, konfrontacji - świata zwierzęcego i ludzkiego (Zwierzęce) oraz gromadzące to, co trudne do wpisania $\mathrm{w}$ wymienione wyżej kategorie oraz zbyt różnorodne, aby tworzyć nową, spójną jakość Inne. Skoro wiemy już co nieco o „niewidzialnym mie-

zowany w Instytucie Socjologii UAM, natomiast zapisując „niewidzialne miasto” (nm), będę miał na myśli fenomen społeczny.

2 Realizowany w Instytucie Socjologii UAM projekt dotyczył - głównie - dużych polskich miast, ich przestrzeni, w rzeczywistości jednak „niewidzialne miasta” mogą istnieć również w miastach mniejszych (choć tam pewnie mniej rzucają się w oczy) oraz, co oczywiste, poza granicami naszego kraju. 
ście" jako takim, przyjrzyjmy się teraz temu, co dla nas istotniejsze, czyli temu, jak powstawała baza danych wizualnych projektu i w jaki sposób była analizowana.

\section{ZBIERANIE, PORZĄDKOWANIE I UPUBLICZNIANIE MATERIALU WIZUALNEGO}

Jak wspomniałem, celem numer jeden projektu NM jest fotograficzna dokumentacja i prezentacja przejawów oddolnego estetyzowania, "łatania" czy po prostu urządzania miasta po swojemu. W sposób zorganizowany dokumentacja prowadzona była w pięciu dużych miastach: Poznaniu, Toruniu, Wrocławiu, Łodzi i Warszawie (później, już po analizie zawartości bazy danych NM, również $\mathrm{w}$ Bydgoszczy), prócz tego w bazie projektu istnieje jeszcze zbiór fotografii $\mathrm{z}$ innych miast, m.in. Tarnowa, Krakowa, Chorzowa i Zielonej Góry, nadesłanych przez ludzi zainteresowanych projektem. Ponieważ cele projektu nakierowane były na duże miasta, a w każdym z nich potrzebna była lokalna komórka organizacyjna, analizie poddane zostały zdjęcia z pięciu pierwszych miast (zbiór fotografii z Bydgoszczy napłynął zbyt późno, w Krakowie natomiast nie było punktu zakotwiczenia). Wracając do etapu zbierania materiału wizualnego, dokumentacje prowadziły jedno- bądź kilkuosobowe zespoły pracujące pod kierownictwem pracowników naukowych z miejscowych uniwersytetów. Osoby te, wyposażone $\mathrm{w}$ aparaty fotograficzne, eksplorowały przydzielony im fragment miasta $\mathrm{w}$ poszukiwania przejawów nm. Na przykład w Poznaniu, gdzie istnieje pięć dużych dzielnic administracyjnych, dokumentację, która trwała około trzech miesięcy ${ }^{3}$, prowadziło sześć osób: trzy osoby przypisane były do jednej dzielnicy, jedna do dwóch, dwie pozostałe przeszukiwały po jednej dzielnicy.

W tym momencie należy poczynić pewną zasadniczą uwagę: w okresie, kiedy ruszały etapy dokumentacyjne (nie tylko poznański, ale w ogóle wszystkie), nie istniały żadne techniczne wytyczne dotyczące trybu fotografowania. Nie chodzi tu jednak o to, że nie było wytycznych odnośnie do sposobu robienia zdjęć, takowe akurat były - od początku chodziło o zdjęcia dokumentacyjne, wolne od ekspresji, intencji autora. Rzecz w tym, iż nie było określone to, jak przerabiać teren na baze danych, na taką bazę danych,

${ }^{3}$ Chodzi o pierwszy i najważniejszy etap poznańskiej dokumentacji, kiedy to zebrano zdjęcia, które stały się podstawą strony internetowej projektu. Etap ten pozwolił po raz pierwszy zobaczyć „niewidzialne miasto" w pełnej krasie i ustanowił mocne fundamenty dla całego projektu. Dokumentacja dokonuje się, rzecz jasna, w sposób ciągły, nie ustała po owych trzech miesiąca, trwa do dziś, choć już z mniejszym natężeniem. 
dodajmy, która będzie przechowywała precyzyjne informacje o charakterze ilościowym. Nie jest to w żadnym razie zarzut pod adresem twórców projektu, nie było takich wytycznych z tej prostej przyczyny, że nikt początkowo nie myślał w ten sposób ani o etapie dokumentacyjnym, ani o samym NM (por. uwagi na początku tekstu o dojrzewaniu projektu „Niewidzialne miasto" do "socjologicznego spożytkowania"). Chodziło tylko o to, aby odnaleźć i pokazać, przeczesać miasto i oddać z niego publiczności to, co niewidzialne. Dlatego też etap dokumentacyjny (i towarzyszący mu etap prezentacyjny, o czym niżej) należałoby raczej uznać za wytwarzanie galerii niewidzialnego miasta, a nie bazy danych wizualnych niewidzialnego miasta. Tę pierwszą - patrząc z perspektywy fotografa dokumentującego nm powołuje do życia ciekawość, fascynacja, autorstwo, chęć zaskoczenia, oczarowania potencjalnego widza, wywarcia na nim silnego wrażenia, drugą ustanawia precyzja, skrupulatność, powtarzalność, bierność, a także nuda i zniechęcenie. Jeśli fotograf odżegnuje się od utrwalania tego, czego zdjęcia już posiada, jeśli nie chce powielać, poszukuje tego, co spektakularne, i zniechęca go to, co zwyczajne - wytwarza galerię; jeśli z mechaniczną precyzją i powtarzalnością fotografuje wszystko, co w najmniejszym stopniu realizuje definicję "niewidzialnego miasta" - wytwarza baze danych. Dokumentaliści nm balansowali pomiędzy jedną a drugą formą materializowania przestrzeni miejskiej $\mathrm{w}$ fotografii, nie wiedzieli, jak postępować z powtarzającymi się rekordami (przejawami nm), nie mieli obowiązku fotografowania każdego przejawu nm, ustalali to sami ze sobą. Powtórzmy jednak: nikt wówczas nie myślał o NM w kategoriach analizy ilościowej.

Bazodanowa formuła zbioru zdjęć zebranych w ramach projektu NM podkopywana była też przez działania koordynatorów. Każdy z nich dokonywał (mowa tu o pierwszych etapach dokumentowania, które odbywało się w sposób zmasowany i systematyczny pod okiem koordynatorów) selekcji dostarczonych fotografii pod kątem ich przydatności, adekwatności, co oznaczało eliminację zdjęć o złej jakości, nieczytelnych, niewykluczone, że również powtarzających się, nudnych, zbyt zwyczajnych (koordynatorzy także mogli ulegać pokusie tworzenia galerii).

To, co napisano wyżej o etapie dokumentacyjnym, dotyczy również etapu prezentacyjnego. Możliwe nawet, iż to tutaj właśnie najsilniej dała o sobie znać (niezdefiniowana i nieartykułowana wówczas) skłonność części twórców projektu do operowania galeria, a nie baza danych. W przypadku pierwszego, poznańskiego upublicznienia "Niewidzialnego miasta” (zainicjowanie istnienia strony-bazy internetowej projektu www.niewidzialnemiasto.pl) odrzucano zdjęcia złej jakości, nie dość jednoznacznie prezentujące "niewidzialne miasto", mało interesujące (czy też mało spektakularne) oraz dublujące znaczenia, prezentujące "coś, czego mamy już bardzo dużo 
zdjęć". Nie chodziło więc tylko o to, aby pokazać nm, chodziło również o to, aby zainteresować nim oglądających, pokazać im coś ciekawego, niebywałego, wywołującego zachwyt i słowa niedowierzania.

$\mathrm{W}$ kolejnym kroku potyczki z „niewidzialnym miastem” utworzonemu $\mathrm{w}$ ten sposób zbiorowi zdjęć zadano rygor ilościowej analizy danych.

\section{MOŻLIWOŚCI ILOŚCIOWEJ ANALIZY BAZ DANYCH WIZUALNYCH, CZYLI O TYM, JAK „PRZERABIANO” FOTOGRAFIE NA DANE ILOŚCIOWE I JAK JE POTEM ANALIZOWANO}

Choć plan socjologicznego opracowania fenomenu "niewidzialnego miasta" towarzyszył autorom projektu niemalże od początku, pierwsze kroki w tym kierunku zostały poczynione $\mathrm{w}$ rok po rozpoczęciu etapu dokumentacyjnego, czyli jesienią 2008 roku, zaś jesienią 2009 roku istniał już schemat i narzędzia ilościowej analizy zawartości bazy danych wizualnych projektu. Poddany badaniu materiał stanowiło 5 tysięcy zdjęć z Poznania, Torunia, Wrocławia, Łodzi i Warszawy4.

Poszukiwano najważniejszych wektorów „niewidzialnego miasta”, odpowiedzi na pytanie, jakie ono właściwie (w ogólności) jest, co jest dla niego najbardziej charakterystyczne, wspólne, powtarzalne, istotne. Prócz konieczności zapanowania nad ogromnym materiałem badawczym, próba ilościowej (czy też parailościowej) analizy zbioru fotografii podyktowana była chęcią ukrócenia, towarzyszącej często analizie zdjęć, samowoli badawczej. Chodziło o to, aby powściągnąć subiektywizm badaczy, ich intuicję, wyobraźnię (owszem, cenną, lecz prowadzącą niekiedy na poznawcze manowce) - „niewidzialne miasto" powinno być odczytywane w sposób systematyczny, uporządkowany, tak obiektywny, jak to tylko możliwe.

Przyjrzyjmy się teraz zaproponowanemu schematowi analizy i zastosowanym $\mathbf{w}$ jego ramach narzędziom. Każdemu z uczestników projektu (chodzi o uczestników, którzy tworzyli "trzon analityczny", czyli około 15 osób) przydzielona została jedna kategoria „niewidzialnego miasta” (przy czym kategorię Inne analizowały dwie osoby, Bramy $i$ ogrodzenia również dwie, a Upiększenia - trzy). W ramach wybranych przez siebie kategorii poszczególni badacze tworzyli subkategorie, typy, ułatwiające zapanowanie nad zbiorem fotografii.

\footnotetext{
${ }^{4}$ Gwoli jasności dodajmy, że proces badania „niewidzialnego miasta” wykraczał poza ilościową analizę zawartości fotografii; inne ważne momenty projektu to wywiady pogłębione z twórcami „niewidzialnego miasta”, badanie reakcji podmiotów instytucjonalnych decydujących o obliczach polskich miast na "niewidzialne miasto”, filmy prezentujące sylwetki twórców nm i kilka innych.
} 
Przykładowe subkategorie, kategoria Reklama:

$\begin{array}{ll}\text { napis } & \text { witryna/gablota/okno wystawowe } \\ \text { graffiti } & \text { totalizacja/nasycenie } \\ \text { zamalowanie/wyodrębnienie } & \text { wystawianie/rozkładanie } \\ \text { kartka papieru } & \text { instalacja/aranżacja/narracja } \\ \text { szyld/tabliczka } & \text { mimikra/kolonizacja }\end{array}$

W kolejnym kroku badacze wybierali od 17 do 43 fotografii (realizacji $\mathrm{nm}$ ), które ich zdaniem najlepiej reprezentują daną kategorię (w założeniu miało to być od 20 do 30 realizacji nm, jednak dla części badaczy zakreślone $\mathrm{w}$ ten sposób terytorium okazało się zbyt ciasne). Liczba fotografii (realizacji nm) przypadających na każdą subkategorię powinna być mniej więcej taka sama. Wybrane zdjęcia kodowane były za pomocą matrycy, pozwalającej umieścić je $\mathrm{w}$ przestrzeni siedmiu analizowanych wymiarów (czas, przestrzeń, funkcja, relacje społeczne, materialność, wykonanie, estetyka), opisanych za pomocą 43 jakości zorganizowanych w opozycje i wyrażonych kodami liczbowymi.

Przykład realizacji nm zakodowanej za pomocą matrycy kodowej (tutaj fragment - trzy pierwsze wymiary i ich jakości opisujące; zorganizowanie jakości w bieguny sprowadza się do kodowania ich za pomocą czterech kodów-stanów: biegun nr 1, mediacja, biegun nr 2, nieklasyfikowalne; przypisany kod znajduje się w ostatniej kolumnie; na końcu matrycy, czego tutaj nie widać, znajdowało się okienko 'uwagi', gdzie osoba kodująca zapisywała swoje refleksje na temat danej realizacji):

\begin{tabular}{|l|l|l|l|l|}
\hline Zr 1] & $\begin{array}{l}\text { Zdjęcie numer: } 6203 \\
\text { Kategoria (1): reklama } \\
\text { Typ: napis } \\
\text { Kod: 1/6203 }\end{array}$ \\
\hline & $\begin{array}{l}\text { Opis: Napis reklamowy wykonany najprawdopodobniej farbą olejną na } \\
\text { tablicy, za która posłużył kawałek dykty bądź blachy, całośc - za pomocą } \\
\text { mocowań z drutu - zawieszona na płocie. }\end{array}$ \\
\hline Zdjęcie5: & \\
\hline
\end{tabular}

${ }^{5}$ Zdjęcie w zasobach projektu „Niewidzialne miasto". 


\begin{tabular}{|c|c|c|c|c|}
\hline \multicolumn{5}{|c|}{ Analiza } \\
\hline $\begin{array}{l}\text { Biegun } 1 \\
\text { (kod: 1) }\end{array}$ & $\begin{array}{l}\text { Mediacja } \\
\text { (kod: } 2 \text { ) }\end{array}$ & $\begin{array}{l}\text { Biegun } 2 \\
\text { (kod: } 3 \text { ) }\end{array}$ & $\begin{array}{l}\text { Nieklasyfi- } \\
\text { kowalne } \\
\text { (kod: } 0 \text { ) }\end{array}$ & $\begin{array}{l}\text { Kodo- } \\
\text { wanie }\end{array}$ \\
\hline \multicolumn{5}{|c|}{ Czas } \\
\hline tymczasowe & & trwałe & & 1 \\
\hline codzienne & & odświętne & & 1 \\
\hline doczesność & & unieśmiertelnianie & & 0 \\
\hline jednorazowe & & cykliczne & & 1 \\
\hline $\begin{array}{l}\text { powstrzymywanie } \\
\text { zmiany }\end{array}$ & & $\begin{array}{l}\text { prowokowanie } \\
\text { zmiany }\end{array}$ & & 3 \\
\hline $\begin{array}{l}\text { Wczoraj } \\
\text { (dawno, PRL) }\end{array}$ & & dzisiaj & & 2 \\
\hline \multicolumn{5}{|c|}{ Przestrzeń } \\
\hline $\begin{array}{l}\text { przestrzeń } \\
\text { prywatna }\end{array}$ & & przestrzeń publiczna & & 2 \\
\hline $\begin{array}{l}\text { mury } \\
\text { (odgradzanie) }\end{array}$ & & mosty (łączenie) & & 2 \\
\hline $\begin{array}{l}\text { zawłaszczanie } \\
\text { (prywatyzowanie) }\end{array}$ & & $\begin{array}{l}\text { upublicznianie } \\
\text { (udostępnianie in- } \\
\text { nym) }\end{array}$ & & 3 \\
\hline $\begin{array}{l}\text { podtrzymanie (pod- } \\
\text { kreślenie) definicji } \\
\text { miejsca }\end{array}$ & & $\begin{array}{l}\text { przeformułowanie } \\
\text { definicji miejsca }\end{array}$ & & 3 \\
\hline \multicolumn{5}{|c|}{ Funkcja } \\
\hline $\begin{array}{l}\text { instrumentalne } \\
\text { (konieczność, zwią- } \\
\text { zek z codzienno- } \\
\text { ścią, prymarnymi } \\
\text { potrzebami) }\end{array}$ & & $\begin{array}{l}\text { autoteliczne } \\
\text { (fanaberia, hobby, } \\
\text { psoty, zabawa) }\end{array}$ & & 1 \\
\hline $\begin{array}{l}\text { dla siebie } \\
\text { (prywatne } \\
\text { potrzeby) }\end{array}$ & & $\begin{array}{l}\text { dla innych } \\
\text { (potrzeby publiczne) }\end{array}$ & & 2 \\
\hline komercyjne & & bezinteresowne & & 1 \\
\hline
\end{tabular}

Ostatecznie badacze przekazali do analizy 401 zakodowanych profili (Architektura - 24 zakodowane realizacje nm, Agory i kluby - 20, Bezpieczeństwo - 19, Bramy i ogrodzenia - 22, Miejsca dziecięce - 22, inne - 26, Mobile - 18, Odświętne - 17, Ogrody - 26, Polityczne-22, Protezy instytucji - 24, Reklamy - 33, Sakralne - 22, Upiększenia - 43, Użyteczne - 23, Zwierzęce - 40).

Analizowane były one dwojako (trzeci tryb analizy, omówiony w kolejnej partii tekstu, choć może funkcjonować jako samodzielne podejście badanie podobieństwa poszczególnych kategorii nm - jest bardziej sprawdzianem trafności całego schematu ilościowej analizy bazy danych wizual- 
nych NM). Pierwsza, samonarzucająca się metoda opracowania profili to przedstawienie odsetków wskazań na każdą pozycję każdej opozycji dla poszczególnych kategorii i całego "niewidzialnego miasta”. Można to zrobić na dwa sposoby:

(a) obierając jako punkt wyjścia opozycje i opisując względem nich poszczególne kategorie nm i całe „niewidzialne miasto”

\begin{tabular}{|c|c|c|c|c|}
\hline \multicolumn{5}{|c|}{$\begin{array}{c}\text { [wymiar nr } 1 \text { / opozycja nr 1] } \\
\text { Czas } \\
\text { Tymczasowe vs. Trwałe }\end{array}$} \\
\hline & $\begin{array}{l}\text { Nieklasyfi- } \\
\text { kowalne }\end{array}$ & Biegun nr 1 & Mediacja & Biegun nr 2 \\
\hline $\begin{array}{l}\text { Ogółem } \\
(\text { „niewidzialne miasto”) }\end{array}$ &, $0 \%$ & $36,7 \%$ & $15,7 \%$ & $47,6 \%$ \\
\hline Architektura &, $0 \%$ & $16,7 \%$ & $50,0 \%$ & $33,3 \%$ \\
\hline Bezpieczeństwo &, $0 \%$ & $57,9 \%$ & $5,3 \%$ & $36,8 \%$ \\
\hline Bramy i ogrodzenia &, $0 \%$ & $9,1 \%$ & $9,1 \%$ & $81,8 \%$ \\
\hline Inne &, $0 \%$ & $38,5 \%$ & $7,7 \%$ & $53,8 \%$ \\
\hline Mobile &, $0 \%$ & $22,2 \%$ & $5,6 \%$ & $72,2 \%$ \\
\hline Odświętne &, $0 \%$ & $100,0 \%$ &, $0 \%$ &, $0 \%$ \\
\hline Ogrody &, $0 \%$ &, $0 \%$ & $15,4 \%$ & $84,6 \%$ \\
\hline Protezy instytucji &, $0 \%$ & $41,7 \%$ & $41,7 \%$ & $16,7 \%$ \\
\hline Reklamy &, $0 \%$ & $39,4 \%$ & $3,0 \%$ & $57,6 \%$ \\
\hline Sakralne &, $0 \%$ & $40,9 \%$ & $22,7 \%$ & $36,4 \%$ \\
\hline Upiększenia &, $0 \%$ & $25,6 \%$ & $9,3 \%$ & $65,1 \%$ \\
\hline Użyteczne &, $0 \%$ & $26,1 \%$ &, $0 \%$ & $73,9 \%$ \\
\hline Zwierzyniec &, $0 \%$ & $40,0 \%$ & $5,0 \%$ & $55,0 \%$ \\
\hline Agory i kluby &, $0 \%$ & $30,0 \%$ & $50,0 \%$ & $20,0 \%$ \\
\hline Miejsca dziecięce &, $0 \%$ & $50,0 \%$ & $22,7 \%$ & $27,3 \%$ \\
\hline Polityczne &, $0 \%$ & $77,3 \%$ & $18,2 \%$ & $4,5 \%$ \\
\hline
\end{tabular}

(b) odtwarzając strukturę matrycy kodowej

\begin{tabular}{|c|c|c|c|c|c|c|}
\hline \multicolumn{7}{|c|}{ Wymiar / Opozycja / Odsetki } \\
\hline Biegun 1 & $\begin{array}{c}\text { Media- } \\
\text { cja }\end{array}$ & Biegun 2 & $\begin{array}{l}\text { Bie- } \\
\text { gun } 1\end{array}$ & $\begin{array}{c}\text { Media- } \\
\text { cja }\end{array}$ & $\begin{array}{l}\text { Bie- } \\
\text { gun } 2\end{array}$ & $\begin{array}{c}\text { Niekla- } \\
\text { sy- } \\
\text { fiko- } \\
\text { walne }\end{array}$ \\
\hline \multicolumn{7}{|c|}{ Czas } \\
\hline tymczasowe & & trwałe & $16,7 \%$ & $50,0 \%$ & $33,3 \%$ & $0,0 \%$ \\
\hline codzienne & & odświętne & $91,7 \%$ & $0,0 \%$ & $8,3 \%$ & $0,0 \%$ \\
\hline doczesność & & $\begin{array}{l}\text { unieśmiertelnia- } \\
\text { nie }\end{array}$ & $50,0 \%$ & $0,0 \%$ & $0,0 \%$ & $50,0 \%$ \\
\hline jednorazowe & & cykliczne & $12,5 \%$ & $25,0 \%$ & $8,3 \%$ & $54,2 \%$ \\
\hline $\begin{array}{l}\text { powstrzymy- } \\
\text { wanie zmiany }\end{array}$ & & $\begin{array}{l}\text { prowokowanie } \\
\text { zmiany }\end{array}$ & $45,8 \%$ & $16,7 \%$ & $25,0 \%$ & $12,5 \%$ \\
\hline
\end{tabular}




\begin{tabular}{|llcccc|}
\hline $\begin{array}{l}\text { Wczoraj } \\
\text { (dawno, PRL) }\end{array}$ & dzisiaj & $12,5 \%$ & $70,8 \%$ & $12,5 \%$ & $4,2 \%$ \\
\hline \multicolumn{5}{c}{ Przestrzeń } \\
\hline $\begin{array}{l}\text { przestrzeń } \\
\text { prywatna }\end{array}$ & $\begin{array}{l}\text { przestrzeń pu- } \\
\text { bliczna }\end{array}$ & $58,3 \%$ & $29,2 \%$ & $8,3 \%$ & $4,2 \%$ \\
\hline $\begin{array}{l}\text { mury } \\
\text { (odgradzanie) }\end{array}$ & mosty (łączenie) & $20,8 \%$ & $62,5 \%$ & $16,7 \%$ & $0,0 \%$ \\
\hline $\begin{array}{l}\text { zawłaszczanie } \\
\text { (prywatyzo- } \\
\text { wanie) }\end{array}$ & $\begin{array}{l}\text { upublicznianie } \\
\text { (udostępnianie } \\
\text { innym) }\end{array}$ & $54,2 \%$ & $33,3 \%$ & $8,3 \%$ & $4,2 \%$ \\
\hline $\begin{array}{l}\text { podtrzymanie } \\
\text { (podkreślenie) } \\
\text { definicji miejsca }\end{array}$ & $\begin{array}{l}\text { przeformuło- } \\
\text { wanie definicji } \\
\text { miejsca }\end{array}$ & $25,0 \%$ & $33,3 \%$ & $20,8 \%$ & $20,8 \%$ \\
\hline
\end{tabular}

Fragment „przeliczonej” matrycy kodowej dla kategorii Architektura

W obydwu przypadkach mamy oczywiście do czynienia z tymi samymi wynikami, zmienia się tylko sposób ich zorganizowania. Dodajmy, że bardziej „ergonomiczny” okazał się pierwszy sposób prezentacji danych.

Drugi sposób analizowania zakodowanych matryc polegał na odnajdywaniu profili (realizacji) typowych, czyli tych, które najsilniej wyrażają, po pierwsze, daną kategorię, po drugie, całe nm. Profile (realizacje) typowe to swego rodzaju węzły znaczeń, momenty, gdzie zawarte jest najwięcej z istoty "niewidzialnego miasta". W pierwszym ruchu wyznaczono profile typowe $\mathrm{w}$ ramach każdej kategorii $\mathrm{nm}$. Podstawą dla ich wskazania były porównania każdego profilu z każdym innym; każde porównanie dokonywało się w przestrzeni 43 opozycji i prowadziło do uzyskania wskaźnika procentowego, gdzie $0 \%$ oznaczało, że na żadnej opozycji nie odnotowano zgodności, a 100\%, że na każdej opozycji odnotowano zgodność (profile identyczne). Jeśli badacz, $\mathrm{w}$ ramach analizowanej przez siebie kategorii, zakodował 20 profili, to każdy profil "staje” do 19 porównań; w sumie dla tylu zakodowanych profili mamy 190 porównań każdy z każdym. A zatem w przypadku tylu zakodowanych profili każdy profil „posiada” 19 wskaźników określających jego podobieństwo z pozostałymi profilami. Z tych 19 wskaźników liczony jest średni wskaźnik procentowy (dla każdego profilu) ten profil, który uzyska najwyższą jego wartość, uznawany jest za najbardziej typowy dla danej kategorii, za węzeł znaczenia. W przypadku poszukiwania profili (realizacji) typowych dla całego "niewidzialnego miasta” do porównań każdy z każdym "stanęły" po trzy profile z każdej kategorii - te, które najsilniej je wyrażały (najwyższe średnie wskaźniki podobieństwa). $\mathrm{Na}$ tym etapie porównywano więc w sumie 48 profili. Oto dwie realizacje, które, zgodnie z przyjętą metodologią, możemy uznać za węzły całego „niewidzialnego miasta" (oczywiście, takich węzłów możemy wskazać więcej; to, czy będzie 2, 5 czy 10 realizacji, zależy wyłącznie od nas). 


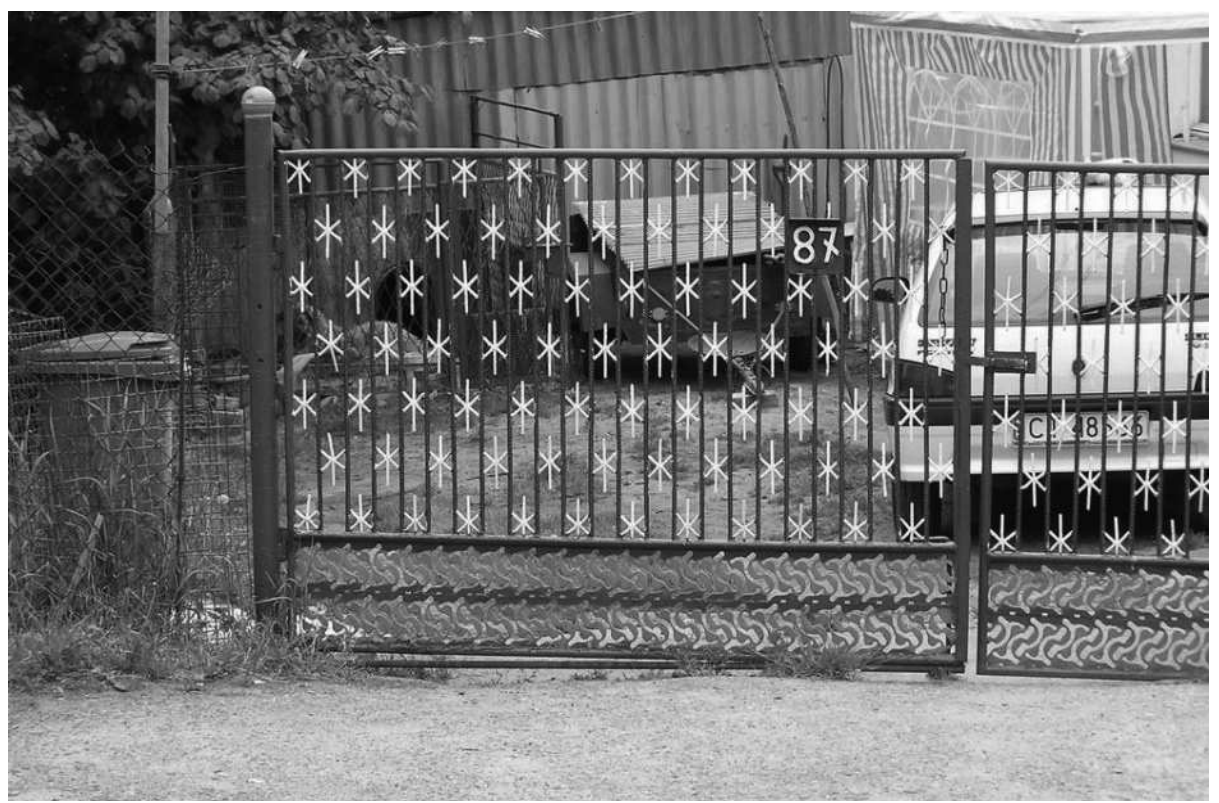

Kategoria Bramy i ogrodzenia, uśredniony wskaźnik podobieństwa na poziomie $53,1 \%$ (w zasobach projektu „Niewidzialne miasto”)

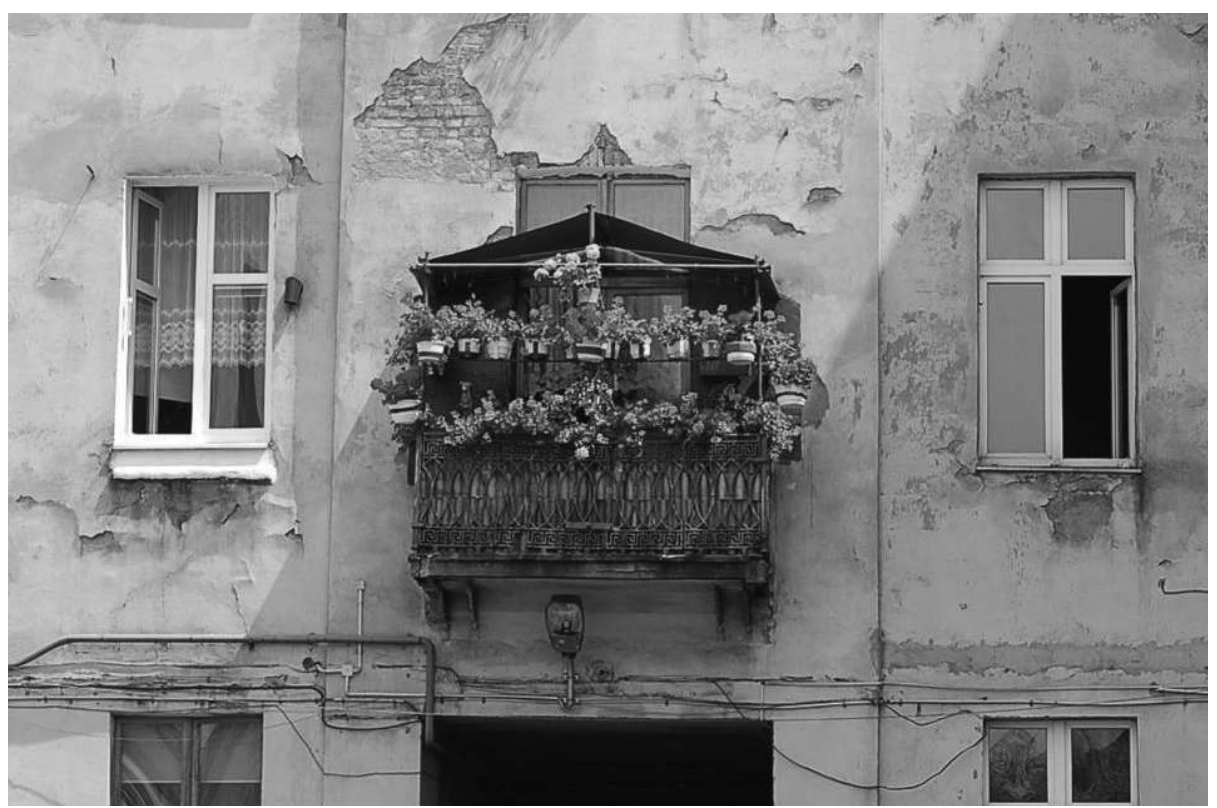

Kategoria Ogrody, uśredniony wskaźnik podobieństwa na poziomie 52,6\% (w zasobach projektu „Niewidzialne miasto”) 
Jeśli czytelnik zadał (zada) sobie trud obejrzenia strony internetowej projektu "Niewidzialne miasto", zgodzi się, że te właśnie realizacje doskonale streszczają istotę prezentowanego tam fenomenu. Mamy tu osobność, samodzielność estetyczną, barwność, rozmaitość, wesołość, wiejskość, kruchość, tryb przeformułowywania otoczenia, odzyskiwania go dla siebie i wbrew czemuś/komuś, a także pewnie kilka innych desygnatów nm.

Prócz tego, iż realizacje typowe już na poziomie fotografii mogą stanowić punkt wyjścia do pogłębionego opisu, mogą też podpowiadać miejsca, gdzie warto się udać, aby przeprowadzić badania (można oczywiście połączyć te dwie formy analizy węzłów $\mathrm{nm}$ ). W takim wypadku udajemy się w miejsca, które „zbierają" najwięcej treści nm (takie też było założenie schematu badawczego przyjętego $\mathrm{w}$ ramach $\mathrm{NM}$, z różnych powodów nie udało się go jednak zrealizować, głównie dlatego, że badacze uznali inne realizacje nm, niewytypowane w toku analizy, za bardziej wartościowe poznawczo).

Tak, pomijając szczegóły techniczne, przebiegała ilościowa analiza zawartości bazy danych NM. Przyjrzyjmy się teraz temu, co podkopuje jej trafność, i zadajmy sobie pytanie, czy w ostatecznym rozrachunku możemy ufać uzyskanym w jej toku wynikom.

\section{OGRANICZENIA I PUŁAPKI ILOŚCIOWEJ ANALIZY BAZ DANYCH WIZUALNYCH}

Trafność ilościowej analizy zawartości bazy projektu „Niewidzialne miasto" może być rozchwiana $\mathrm{z}$ dwóch zasadniczych powodów: (1) ze względu na zaburzoną reprezentatywność (realizacje wytypowane do "analizy profilowej” ( $(n=401)$ stanowią $\mathrm{w}$ takim przypadku próbkę „niewidzialnego miasta") oraz (2) ze względu na subiektywizmy badaczy mogące ujawnić się na etapie kodowania profili.

Zacznijmy od problemu reprezentatywności ${ }^{6}$. Czy rozkłady procentowe uzyskane $\mathrm{w}$ wyniku zbiorczej analizy profili mówią prawdę o „niewidzialnym mieście"? Czy 70\% w ramach 401 profili równa się $70 \%$ w terenie? Czy w końcu, mówiąc językiem statystyki, wytypowane 401 profili możemy uznać za próbkę reprezentatywną? Aby odpowiedzieć na te pytania, musimy najpierw ustalić momenty, gdzie - w przypadku projektu „Niewidzialne miasto" - reprezentatywność jest realizowana albo tracona.

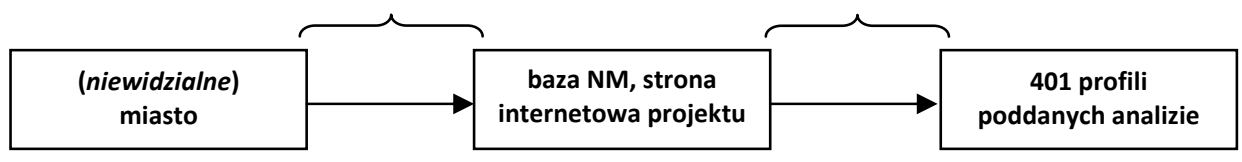

6 Pomijam tu definiowanie reprezentatywności; należy ją rozumieć w ten sam sposób, w jaki jest ona rozumiana na gruncie statystyki (i języka potocznego, dodajmy). 
Powyższy schemat podpowiada, że mamy trzy poziomy występowania danych i dwa momenty realizowania/tracenia reprezentatywności w procesie ich transportowania i porządkowania. Przyjrzyjmy się pierwszemu $\mathrm{z}$ nich.

W założeniu osoby dokumentujące miały jak najdokładniej przeczesać przydzielony im fragment miasta i znaleźć jak najwięcej przejawów nm. Wiele zależało więc tutaj od fotografów, ich chęci, rzetelności, skrupulatności, uczciwości. Należy jednak przyjąć, że punktem wyjścia dla bazy NM była transmisja danych $\mathrm{w}$ stosunku 1:1 (oczywiście, nikt nie formułował takiego założenia wprost, wynikało ono jednak implicite $\mathrm{z}$ organizacji procesu dokumentacji - oddelegowane w teren osoby musiały odszukać "niewidzialne miasto", de facto więc fotografowały wszystko, co mieściło się w jego pierwszej definicji). Jak już jednak pisałem, założenie to nie zostało zrealizowane (nie mogło zostać zrealizowane) nie tylko z powodu przeoczeń, przemilczeń i zaniechań fotografów, ale także piętna, jakie na bazie NM odcisnęli koordynatorzy i moderatorzy strony internetowej projektu. Tak zatem - kodyfikując ten wątek - baza NM nie może rościć sobie prawa do bycia doskonałą bądź bliską doskonałości reprezentacją „niewidzialnego miasta" z powodu (1) nierzetelności osób wykonujących zdjęcia oraz (2) selektywności fotografów, koordynatorów i moderatorów strony internetowej projektu (pomijanie tego, czego zdjęcia już się posiada, znudzenie, nastawienie na to, co spektakularne, odrzucanie zdjęć niezrozumiałych, nieczytelnych, złej jakości - o czym była już mowa). Zwróćmy przy tym uwagę na jedną bardzo ważną rzecz. Eliminowanie z (odcinanie od) bazy zdjęć (realizacji) dublujących znaczenia jest równoznaczne $\mathrm{z}$ eliminowaniem tego, czego w "niewidzialnym mieście” jest najwięcej, jest więc podkopywaniem zasady badania ilościowego. $W$ badaniu ilościowym nie istnieje problem zdublowanego znaczenia, bowiem w ten właśnie sposób wytwarza się znaczenia na gruncie tego rodzaju badań. Tak opisywany tryb selektywności był zatem jednym $\mathrm{z}$ najważniejszych czynników destabilizujących ilościowy charakter bazy NM.

Drugi moment realizowania/tracenia reprezentatywności to etap wyboru zdjęć (realizacji) do analizy profilowej, moment przejścia od liczącej około 5 tysięcy zdjęć bazy do liczącej 401 rekordów próbki właściwej, tej, która została poddana analizie. Przypomnijmy tryb tej procedury. Do każdej kategorii $n m$ przypisany był jeden badacz ( $w$ dwóch przypadkach reguła ta została złamana), który tworzył $\mathrm{w}$ ramach kategorii subkategorie (typy), a następnie zapełniał je kilkoma zdjęciami, takimi, które jego zdaniem najlepiej owe subkategorie wyrażały. Dopowiedzmy ponadto, że liczności kategorii $\mathrm{nm}$ nie były i nie są równe - $\mathrm{w}$ momencie przeprowadzenia analizy ilościowej najliczniejszą kategorią były Upiększenia, do których przypisano 
1189 realizacji, zaś najmniej liczną Mobile ze 115 realizacjami. Jakich problemów, w kontekście zagadnienia reprezentatywności, nastręcza dobór dokonany na potrzeby analizy profilowej? Otóż musimy rozstrzygnąć, czy powinien on uwzględniać ilościowe relacje pomiędzy (a) kategoriami nm i (b) subkategoriami w ramach każdej kategorii (dobór proporcjonalny). Czy jeśli Upiększeń jest 10 razy więcej niż Mobili, to do etapu właściwej analizy ilościowej powinno „przedostać się" 10 razy więcej zdjęć z tej kategorii w stosunku do Mobili? Czy jeśli w ramach kategorii Reklama jest 5 razy więcej napisów aniżeli strategii mimikry/kolonizacji, to czy mamy tę relację uwzględnić $\mathrm{w}$ momencie tworzenia próby?

Zacznijmy od kwestii relacji pomiędzy głównymi kategoriami nm. Na gruncie socjologii naturalną strategią jest dobór proporcjonalny, w przypadku "niewidzialnego miasta" nie odtworzyłby on jednak prawdziwego obrazu rzeczywistości i sprowadziłby nas na manowce. Jest tak, ponieważ wszystkie kategorie nm (składowe zjawiska społecznego, a nie bazy danych) są tak samo ważne, są "niewidzialnym miastem” w takim samym stopniu. Decyzja o odtwarzaniu relacji ilościowych jest równoznaczna z decyzją, że Upiększenia są bardziej „niewidzialnym miastem” aniżeli Mobile, że napis jest znaczniejszą jego częścią niż strategia mimikry etc., co jest oczywiście nieprawdą. Dodajmy przy tym, iż dynamika ujawniania się poszczególnych zjawisk (czyli kategorii, mówiąc językiem analizy) w ramach $\mathrm{nm}$ jest różna. Nie można oczekiwać, że w mieście pojawia się tyle samo własnoręcznie udoskonalonych/przerobionych/przeinaczonych samochodów co przydomowych ogrodów - to pierwsze to odstępstwo od normy, drugie - niemalże norma ( $\mathrm{w}$ pewnych rejonach miasta na pewno, np. na przedmieściach czy osiedlach domków jednorodzinnych). Nie można zestawiać ilości reklam z ilością pozainstytucjonalnych miejsc materializowania się religii, ilości użytecznych usprawnień zwiększających funkcjonalności środowiska życia z ilością półlegalnych miejsc spotkań (Agory i kluby). Dobór proporcjonalny dekonstruuje takie zjawiska, jak "niewidzialne miasto”. W toku ilościowej analizy bazy NM zrównano wagę wszystkich kategorii, każda z nich zajęła właściwe sobie miejsce - tak samo ważnej części „niewidzialnego miasta".

Problem relacji ilościowych w ramach poszczególnych kategorii jest trochę zagmatwany. Decyzja, czy decydować się na dobór proporcjonalny, czy na dobór oparty na równych wagach, zależy od stopnia wewnętrznej spójności danej kategorii. Jeśli kategoria jest spójna, czyli jeśli wszystkie przypisane do niej realizacje organizuje jedna, łatwo zauważalna zasada, powinniśmy zastosować dobór proporcjonalny. Liczności poszczególnych subkategorii pokazują wówczas, w jakich trybach dane zjawisko się realizuje, co jest dla 
niego bardziej charakterystyczne, jakie modusy zdarzają się częściej. Spójne kategorie to na przykład Reklama, Ogrody, Mobile. Weźmy tę pierwszą - jeśli strategia mimikry/kolonizacji bądź instalacji/aranżacji/narracji realizowana (wybierana) jest rzadziej niż reklama w formie tabliczki bądź zwykłej kartki papieru, to taka właśnie jest formuła niewidzialnomiejskiej reklamy i powinniśmy ją zachować, chcąc poznać „niewidzialne miasto”. Jeśli kategoria nie jest spójna wewnętrznie, jeśli kumulują się w niejraczej niezależne zjawiska, które, wskutek decyzji twórców projektu, zostały zebrane w jedno, powinniśmy zastosować dobór oparty na równych wagach. Kategorie niespójne to na przykład Bezpieczeństwo (unieruchomienia, bariery, monitoring, ostrzeżenia/pogróżki), Protezy instytucji (drugi obieg, kontestacje, regulacje, uobecnienia, zasłony) czy też Sakralne (ekspresje wartości, ochraniacze, upamiętnienia, zworniki społeczności). Unieruchomienia (np. łańcuch przytwierdzający ławkę do podłoża) to inna jakość niż monitoring (lusterko, za pomocą którego można podglądać osoby wchodzące do klatki); drugi obieg (oferty sprzedaży, zakupu, wynajmu wieszane w przestrzeni publicznej) różni się znacząco od kontestacji („przytwierdzone do miasta" hasła o charakterze politycznym), podobnie jak ekspresje wartości (przydrożna bądź osiedlowa figurka) od upamiętnień (krzyż upamiętniający ofiarę wypadku samochodowego).

W przypadku kategorii charakteryzujących się wewnętrznym rozproszeniem musimy postąpić tak jak w przypadku całego „niewidzialnego miasta" - nie możemy podporządkowywać jednej kategorii drugiej ze względu na liczność, mamy bowiem do czynienia z odrębnymi zjawiskami, które nie układają się na jednym wektorze: więcej jednej nie oznacza mniej drugiej. Przypomnijmy jeszcze tylko, iż przyjęty w ramach projektu NM schemat doboru zdjęć (realizacji) do próbki stanowiącej materiał dla analizy ilościowej (próbka utworzona w toku analizy profilowej) zakładał, że liczba zdjęć dla każdej subkategorii powinna być mniej więcej równa.

Zajmijmy się teraz drugim czynnikiem mogącym podkopywać trafność ilościowej analizy zawartości bazy NM - subiektywizmami badaczy kodujących zdjęcia za pomocą prezentowanej we wcześniejszych partiach tekstu matrycy. Jak pamiętamy, każda z 16 kategorii nm kodowana była przez innego badacza (dla porządku przypomnijmy, że kategorię Upiększenia kodowały trzy osoby, Inne - dwie, Bramy i ogrodzenia również dwie), $\mathrm{w}$ toku analizy uaktywniło się więc i oddziaływało na jej wynik kilkanaście subiektywnych punktów widzenia, sum doświadczeń, sądów, gustów, z czego wynika niebezpieczeństwo rozchwiania analizy, bardzo bowiem możliwe, iż przy tylu subiektywizmach te same jakości, stany rzeczy, były kodowane inaczej, za pomocą innych (subiektywnych) kodów. Rozchwia- 
nie to potęgował dodatkowo fakt, że niektóre opozycje pozostawiały spory margines interpretacji, aplikowały się do rzeczywistości w sposób niejednoznaczny, zmuszały badaczy do wprawienia $\mathrm{w}$ ruch wiedzy (naukowej i potocznej) i wyobraźni, (subiektywnego) wczuwania się w realizację. Weźmy takie opozycje, jak: powstrzymywanie zmiany vs prowokowanie zmiany, mury (odgradzanie) vs mosty (taczenie), dla siebie (prywatne potrzeby) vs dla innych (potrzeby publiczne), reprezentacja ja vs reprezentacja my, chaotycznie vs zgodnie $z$ projektem. Oczywiście, każdy potrafi wpisać w nie na przykład tabliczkę reklamową, ale czy będą to zawsze te same kody? A przecież chodzi wciąż o ten sam przedmiot, o te same jakości. Na drodze do obiektywnego obrazu „niewidzialnego miasta" stanęło więc kilkanaście subiektywizmów.

\section{WERYFIKACJA SCHEMATU ILOŚCIOWEJ ANALIZY ZAWARTOŚCI BAZ DANYCH WIZUALNYCH PROJEKTU „NIEWIDZIALNE MIASTO”}

Znamy już czynniki, które podkopują trafność ilościowej analizy bazy NM, mamy też obawy odnośnie do reprezentatywności próbki, która została poddana analizie ilościowej, i nie mamy pewności, czy analiza obroniła się przed wpływem subiektywizmów badaczy kodujących realizacje za pomocą matryc. Powtórzmy zatem postawione wcześniej pytanie: czy 70\% w ramach 401 profili równa się $70 \%$ w terenie (mieście)? Pomimo wyżej nakreślonych zagrożeń, odpowiedź na to pytanie brzmi: tak (oczywiście przy założeniu tolerancji dla pewnych, niemających decydującego znaczenia, odchyleń). Trafność ilościowej analizy bazy danych NM można sprawdzić za pomocą dwóch analiz wielowymiarowych, ujawniających ukryte wzory tkwiące $\mathrm{w}$ zbiorach danych - mowa o wielowymiarowej analizie korespondencji (w skrócie MCA, nazywanej również analizą homogeniczności, w skrócie HOMALS) oraz o analizie skupień. Tutaj skoncentrujemy się na omówieniu sprawdzianu z wykorzystaniem analizy skupień, ponieważ dała ona lepsze rezultaty.

Krótko powiemy o tym, jak utworzono dostosowaną do jej wymogów bazę danych. Pierwszy krok to decyzja, że każda kategoria nm reprezentowana będzie $\mathrm{w}$ analizie przez jedną realizację, tę, która jest dla niej najbardziej typowa (zob. wcześniejsze fragmenty tekstu, gdzie omówiony jest etap wyznaczania realizacji typowych). $W$ kolejnym ruchu skonstruowano bazę, w której w wierszach znajdują się kategorie nm (obserwacje), a w kolumnach opozycje (zmienne) - jest to standardowy układ każdego pakietu statystycznego (zob. tabela poniżej). 


\begin{tabular}{|l|c|c|c|c|c|c|c|}
\hline $\begin{array}{l}\text { Kategoria (realizacja } \\
\text { najbardziej } \\
\text { typowa) }\end{array}$ & op_1 & op_2 & op_3 & op_4 & op_5 & op_6 & op_7 \\
& & & & & & \\
\hline Architektura & 3 & 1 & 0 & 0 & 0 & 2 & 2 \\
\hline Bezpieczeństwo & 1 & 1 & 1 & 1 & 1 & 3 & 2 \\
\hline Bramy i ogrodzenia & 1 & 1 & 1 & 1 & 1 & 3 & 1 \\
\hline Inne & 3 & 1 & 1 & 1 & 0 & 3 & 3 \\
\hline Mobile & 3 & 1 & 1 & 1 & 2 & 3 & 2 \\
\hline Odświętne & 1 & 3 & 1 & 3 & 3 & 3 & 3 \\
\hline Ogrody & 3 & 1 & 1 & 1 & 1 & 3 & 1 \\
\hline Protezy instytucji & 1 & 1 & 1 & 1 & 0 & 3 & 3 \\
\hline Reklamy & 3 & 1 & 0 & 1 & 3 & 2 & 3 \\
\hline Sakralne & 3 & 1 & 3 & 1 & 1 & 2 & 2 \\
\hline Upiększenia & 3 & 1 & 3 & 1 & 0 & 3 & 1 \\
\hline Użyteczne & 3 & 1 & 1 & 1 & 0 & 3 & 1 \\
\hline Zwierzęce & 3 & 1 & 1 & 1 & 1 & 3 & 3 \\
\hline Agory i kluby & 1 & 1 & 1 & 3 & 2 & 2 & 1 \\
\hline Miejsca dziecięce & 1 & 1 & 1 & 3 & 3 & 3 & 1 \\
\hline Polityczne & 2 & 1 & 1 & 1 & 3 & 3 & 3 \\
\hline
\end{tabular}

Aby analiza skupień stała się możliwa, należało jeszcze przekodować każde wskazanie, np. kod 3 dla architektury i opozycji nr 1, na system skojarzonych zmiennych zero-jedynkowych (analiza skupień nie może pracować ze zmiennymi nominalnymi wielokategorialnymi, każdą taką zmienną możemy jednak przerobić na system skojarzonych zmiennych binarnych, które nadają się do analizy). Po przekodowaniu nasza baza przedstawia się następująco (fragment z dwiema przekodowanymi opozycjami):

\begin{tabular}{|l|c|c|c|c|c|c|c|c|}
\hline $\begin{array}{l}\text { Kategoria (realizacja } \\
\text { najbardziej } \\
\text { typowa) }\end{array}$ & op1_0 & op1_1 & op1_2 & op1_3 & op2_0 & op2_1 & op2_2 & op1_3 \\
\hline Architektura & 0 & 0 & 0 & 1 & 0 & 1 & 0 & 0 \\
\hline Bezpieczeństwo & 0 & 1 & 0 & 0 & 0 & 1 & 0 & 0 \\
\hline Bramy i ogrodzenia & 0 & 1 & 0 & 0 & 0 & 1 & 0 & 0 \\
\hline Inne & 0 & 0 & 0 & 1 & 0 & 1 & 0 & 0 \\
\hline Mobile & 0 & 0 & 0 & 1 & 0 & 1 & 0 & 0 \\
\hline Odświętne & 0 & 1 & 0 & 0 & 0 & 0 & 0 & 1 \\
\hline Ogrody & 0 & 0 & 0 & 1 & 0 & 1 & 0 & 0 \\
\hline Protezy instytucji & 0 & 1 & 0 & 0 & 0 & 1 & 0 & 0 \\
\hline Reklamy & 0 & 0 & 0 & 1 & 0 & 1 & 0 & 0 \\
\hline
\end{tabular}




\begin{tabular}{|l|l|l|l|l|l|l|l|l|}
\hline Sakralne & 0 & 0 & 0 & 1 & 0 & 1 & 0 & 0 \\
\hline Upiększenia & 0 & 0 & 0 & 1 & 0 & 1 & 0 & 0 \\
\hline Użyteczne & 0 & 0 & 0 & 1 & 0 & 1 & 0 & 0 \\
\hline Zwierzęce & 0 & 0 & 0 & 1 & 0 & 1 & 0 & 0 \\
\hline Agory i kluby & 0 & 1 & 0 & 0 & 0 & 1 & 0 & 0 \\
\hline Miejsca dziecięce & 0 & 1 & 0 & 0 & 0 & 1 & 0 & 0 \\
\hline Polityczne & 0 & 0 & 1 & 0 & 0 & 1 & 0 & 0 \\
\hline
\end{tabular}

Indeksy oznaczają: 0 - nieklasyfikowalne; 1 - biegun nr 1; 2 - mediacja, 3 - biegun nr 2. Jeśli poprzednio architektura na opozycji nr 1 uzyskała wskazanie 3 (biegun nr 2), to teraz uzyskuje wskazanie 1 na subopozycji op1_3 i zera na subopozycjach op1_0, op1_1, op1_2. Dodajmy jeszcze, że przed analizą skupień usunięto wszystkie subopozycje z indeksem 0 (nieklasyfikowalne), aby uniknąć zjawiska współliniowości zmiennych, niewskazanego w przypadku tej analizy.

Mówiąc najogólniej, analiza skupień (ang. clusteranalysis) jest techniką, za pomocą której jesteśmy w stanie grupować obserwacje ${ }^{7} \mathrm{w}$ homogeniczne grupy na podstawie zestawu wybranych przez nas zmiennych. Na przykład jeśli wyznaczymy kilka zmiennych opisujących polskie miasta - niech będzie to liczba ludności, obszar, długość linii tramwajowej, wskaźnik bezrobocia, wskaźnik przestępczości (wyrażony ilościowo) i liczba studentów i poddamy utworzony $w$ ten sposób zbiór danych analizie skupień, to te miasta, które ze względu na przyjęte $\mathrm{w}$ analizie zmienne są najbardziej do siebie podobne, utworzą klastry, zostaną przez analizę wskazane jako podobne do siebie ${ }^{8}$. Na tej samej zasadzie możemy pogrupować kategorie „niewidzialnego miasta" (obserwacje) ze względu na 43 opozycje (zmienne), a analiza skupień wskaże, które kategorie (zjawiska) są do siebie podobne. $\mathrm{W}$ tym momencie możemy przejść do istoty sprawdzianu trafności ilościowej analizy bazy danych NM za pomocą techniki analizy skupień. Otóż, przeprowadzone analizy są trafne (próba jest reprezentatywna, wpływ subiektywizmów badaczy na kodowanie nie był znaczący), jeśli bazująca na tych samych danych analiza skupień właściwie powiąże kategorie "niewidzialnego miasta”, jeśli poprawnie odtworzy ich podobieństwa. Punktem wyjścia jest tu zatem ustalone a priori podobieństwo pomiędzy kategoriami $\mathrm{nm}$. Wprowadzenie takiego ustalenia nie jest równoznaczne $\mathrm{z}$ narzucaniem rzeczywistości wizji badacza. Podobieństwo niektórych kategorii

7 Możemy grupować również zmienne, nie wspominam jednak o tym, aby nie komplikować niepotrzebnie wywodu.

8 Oczywiście, i bez analizy skupień wiemy, które miasta są do siebie podobne, to tylko przykład; zazwyczaj tę technikę stosuje się w sytuacjach braku wiedzy o podobieństwie badanych jednostek, np. gdy chcemy wskazać homogeniczne grupy wśród wyborców danego polityka. 
(zjawisk) jest dość oczywiste, nie potrzeba pogłębionej analizy, aby je dostrzec. Przejawia się ono następująco.

Podobieństwo a priori (liczba w nawiasie kwadratowym oznacza przypisanie do grupy; jeśli wpisanych jest więcej liczb, znaczy to, że kategoria plasuje się $\mathrm{w}$ kilku grupach, brak liczby oznacza niemożność przypisania kategorii do grupy w trybie a priori):

\begin{tabular}{|ll}
\hline Architektura & Ogrody [2] \\
Bezpieczeństwo [1] & Protezy instytucji [1,3] \\
Bramy i ogrodzenia [2] & Reklamy \\
Inne [3] & Sakralne \\
Mobile & Upiększenia [2] \\
Odświętne & Użyteczne [1] \\
Zwierzyniec & Agory i kluby [4] \\
Miejsca dziecięce [4] & Polityczne [3]
\end{tabular}

Grupa pierwsza - Bezpieczeństwo, Protezy instytucji, Użyteczne - to momenty łatania miasta, usprawniania go, reperowania, majsterkowania przy nim. Zjawiska przyporządkowane do tych trzech kategorii spaja podobieństwo: potrzeb, na które odpowiadają, usytuowania w przestrzeni miejskiej oraz estetyki (o ile można o takowej mówić w tym przypadku). Grupa druga - Bramy i ogrodzenia, Ogrody, Upiększenia - to formy, których główną funkcją jest estetyzacja. Grupa trzecia - Inne, Protezy instytucji, Polityczne to przede wszystkim nieformalne przejawy protestu, upominania, zakazywania, obśmiewania, ale i wypowiadania uczuć; spaja je medium (duża i mała architektura) oraz użyte środki (kartka papieru, ręka i długopis, wydruk komputerowy, puszka farby). Zwracam uwagę, że w ramach kategorii Inne większość realizacji stanowią rozmaite napisy umieszczane $\mathrm{w}$ przestrzeni miast, od wyznań natury egzystencjalnej („Nie piję!”), przez ogłoszenia o pracę, po deklaracje przywiązania do barw klubowych (kibice). Podobna uwaga dotyczy Protez instytucji: choć są one bliskie Użytecznym i Bezpieczeństwu, znaczna (chyba nawet większa) ich część to pozainstytucjonalne zakazy, nakazy, wszelkiego rodzaju instrukcje obowiązujące dla danego fragmentu miasta. Połączenie kategorii w grupie czwartej - Miejsca dziecięce oraz Agory i kluby - może zrazu dziwić, mamy wszak do czynienia $\mathrm{z}$ zupełnie różnymi miejscami, w których realizują się całkiem inne sposoby spędzania czasu (wolnego), pod pewnymi jednak względami są one do siebie podobne: i Agory i kluby, i Miejsca dziecięce to nieformalne miejsca spotkań, ukryte przed miastem oficjalnym i przez nie nieakceptowane. W oby$\mathrm{dwu}$ przypadkach stykamy się $\mathrm{z}$ braniem $\mathrm{w}$ nawias oficjalnego porządku, przechodzeniem $w$ przestrzeń zabawy, karnawału; miejsca te łączy też usy- 
tuowanie i estetyka - są to szczeliny i zakątki miasta, miejsca brudne. Sprawdźmy teraz, jak do tych ustaleń mają się wyniki analizy skupień 9

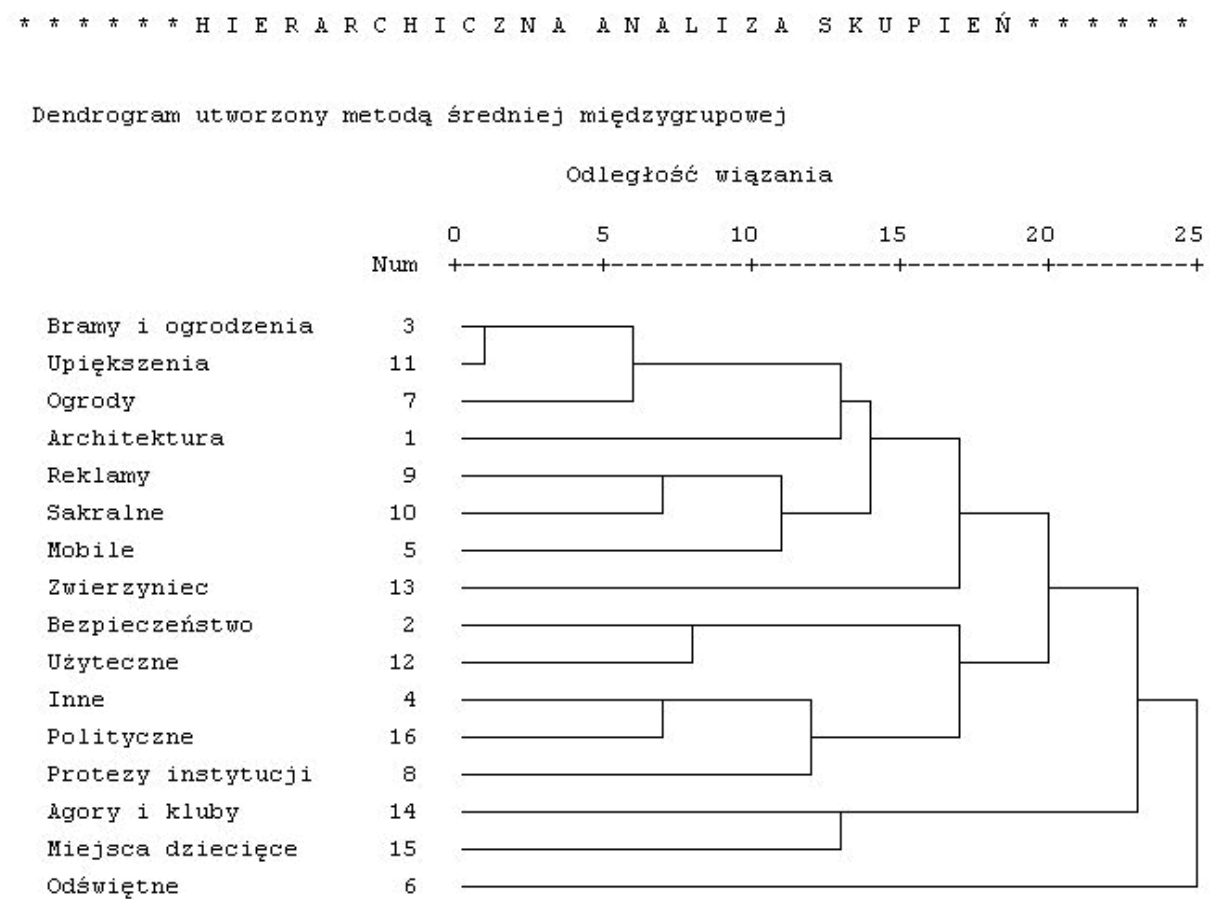

Wynik grupowania przedstawiany jest najczęściej za pomocą tzw. dendrogramu. Wykres taki jak powyższy czytamy z lewej do prawej; po lewej stronie mamy kategorie $\mathrm{nm}^{10}$, po prawej ich "gałęzie"; im bardziej dwie kategorie (lub sploty kategorii) są do siebie podobne, tym wcześniej ich "gałęzie" splatają się ze sobą (miarą "czasu" potrzebnego do połączenia dwóch kategorii lub splotów kategorii jest długość linii). Gwoli jasności, hierarchiczna analiza skupień zmierza do tego, aby w ostatnim kroku analizy utworzyć jedno, ostateczne skupienie (w naszym przypadku jest to moment dołączenia odświętnych do reszty kategorii). Zadanie badacza polega na tym, aby „zatrzymać” ją tam („przeciąć” dendrogram), gdzie widzi on najlepsze rozwiązanie - zwykle robi się to $\mathrm{w}$ momencie, gdy "gałęzie" stają

${ }^{9} \mathrm{~W}$ omawianym przypadku hierarchiczna analiza skupień dla danych binarnych została przeprowadzona metodą średniej międzygrupowej, gdzie miarą podobieństwa była Miara Dice'a.

10 Widoczne na wykresie numery (kolumna Num) to kody kategorii przypisane im w to$\mathrm{ku}$ analizy. Nie mają one dla nas większego znaczenia i nie wpływały w żaden sposób na samą analizę. 
się stosunkowo długie, co oznacza, że algorytm ma spore problemy, aby "dopatrzeć się" podobieństwa pomiędzy pozostającymi w analizie kategoriami (wiązkami kategorii). Wracając do meritum, okazuje się, iż analiza skupień potwierdza założenia a priori: najwyraźniej wyodrębnia się grupa nr 1, czyli grupa estetyzacji (Bramy i ogrodzenia, Upiększenia, Ogrody); analiza „dopatruje się" również wyraźnego podobieństwa pomiędzy Innymi a Politycznymi i niedługo potem dołącza do nich Protezy instytucji (grupa $\mathrm{nr} 3$ ). Obok tej grupy plasuje się grupa utworzona przez Użyteczne i Bezpieczeństwo (grupa nr 1). Zwróćmy uwagę, że w kolejnych krokach grupa ta dołączana jest do wiązki, w której są Protezy instytucji - to one właśnie, jako usytuowane pomiędzy tymi dwiema grupami, decydują o owym połączeniu. Połączone zostają również Miejsca dziecięce oraz Agory i kluby (grupa nr 4), co więcej, analiza doskonale oddaje istotę tego splotu: jak pamiętamy, są to miejsca podobne, ale zarazem niepodobne do siebie; $\mathrm{w}$ toku analizy bardzo długo tworzą odrębną wiązkę, a połączenie ich w jedno nie następuje szybko. Wykres podpowiada też, iż zjawiskami odstającymi od głównego nurtu „niewidzialnego miasta" są Odświętne oraz Zwierzęce, co specjalnie nie dziwi i wydaje się zgodne z prawdą. Odstaje również Architektura, ale w mniejszym stopniu. Frapująca jest natomiast wiązka utworzona przez Sakralne i Reklamy, do której po pewnym czasie dołączane są Mobile. Nie do końca można znaleźć wytłumaczenie dla tego splotu, być może chodzi tu o architektoniczność owych realizacji, a przy tym jarmarczność, odpustowość, ludowość. Ogólnie jednak możemy stwierdzić, że analiza skupień potwierdziła założenia a priori, a co za tym idzie i co najważniejsze, ilościowa analiza zawartości bazy danych wizualnych projektu "Niewidzialne miasto" jest trafna.

\section{KILKA SŁÓW NA ZAKOŃCZENIE}

Okazuje się zatem, że wskazane wyżej zagrożenia dla schematu analitycznego bazy danych wizualnych NM miały mniejsze znaczenie, niż podejrzewano. Dlaczego tak się stało? Najwyraźniej przeszukujący teren fotografowie okazali się rzetelni i nie na tyle selektywni, aby podkopać reprezentatywność zbioru zdjęć; selektywność koordynatorów i moderatorów strony internetowej również okazała się mniejsza, niż można by przypuszczać. Zasada równej wagi wszystkich subkategorii w ramach kategorii na etapie doboru zdjęć do analizy profilowej nie zdestabilizowała istotnie tych kategorii, w przypadku których wskazana była reguła doboru proporcjonalnego. Prawdopodobnie oznacza to, iż kategorii niespójnych wewnętrznie, w odniesieniu do których zalecany jest dobór oparty na rów- 
nych wagach, jest w ramach nm więcej. Analiza okazała się też odporna na subiektywizmy badaczy na etapie kodowania zdjęć za pomocą matrycy kodowej. Jest tak najpewniej dlatego, że wszyscy oni rekrutowali się z obszaru szeroko rozumianych nauk społecznych, mieli stosowną świadomość metodologiczną i potrafili kontrolować swoje decyzje kodowe. Nie bez znaczenia było zapewne i to, iż ewentualność zaburzenia analizy przez subiektywizm była głośno dyskutowana przed przystąpieniem do kodowania, co musiało wyostrzyć czujność uczestników projektu. Czy wobec tego powinniśmy uznać wskazane w tekście zagrożenia za mało istotne i nie przejmować się nimi w przyszłości? Nie, wręcz przeciwnie, trzeba zdawać sobie z nich sprawę i z tą wiedzą projektować podobne badania. Nigdy nie będziemy wiedzieć, jak przedstawiałyby się wyniki analizy bazy NM, gdyby przeprowadzić ją pod dyktando spisanego wyżej rygoru metodologicznego (dotyczy to również etapu fotografowania, tworzenia bazy). Być może „niewidzialne miasto" zostałoby rozpoznane jeszcze lepiej. 